\title{
MODERNISASI POLA SISTEM PENDIDIKAN PESANTREN: Studi Kasus Pondok Pesantren Modern Daarul Fikri Mulyoagung Dau Malang
}

\author{
Eko Setiawan \\ Pascasarjana Sosiologi Fakultas Pertanian Universitas Brawijaya Malang \\ Telp: 085755597774 \\ email: oke.setia@gmail.com
}

\begin{abstract}
Pesantren is a native Indonesian educational institution having a strong tradition root within the community. In the era of modernization or the advancement of science and technology today, pesantren education system is maintained. This study aims at identifying the modernization model of pesantren education, the plus and minus of its modernization, and the modern pesantren patterns. The design of qualitative research is used with a case study model. The data collection techniques employ participant observation, in-depth interviews, and documentary studies. The analysis shows that the modernization in Pesantren Daarul Fikri is very different from other Islamic pesantrens in Indonesia. It has implemented a very strict curriculum. Students must obey all of the rules in regular education. Its curriculum combines the classical tradition and modern style applied well in both the teaching and learning system.
\end{abstract}

Pesantren merupakan lembaga pendidikan asli Indonesia yang mempunyai akar tradisi kuat di lingkungan masyarakat. Dalam era modernisasi atau kemajuan ilmu pengetahuan dan teknologi dewasa ini, sistem pendidikan pesantren tetap dipertahankan. Penelitian ini bertujuan mengetahui model modernisasi pendidikan pesantren, plus minus modernisasi pendidikan pesantren, dan pola pesantren modern. Desain penelitian kualitatif digunakan dengan model studi kasus. Teknik pengumpulan data menggunakan observasi partisipatif, wawancara mendalam, dan studi dokumenter. Hasil analisis menunjukkan bahwa modernisasi di Pesantren Daarul Fikri sangat berbeda dengan pesantren- 
pesantren lain di Indonesia. Pesantren ini telah memberlakukan kurikulum yang sangat ketat. Santri harus mematuhi seluruh peraturan dalam pendidikan reguler. Kurikulumnya mencoba memadukan antara tradisi belajar klasik dan gaya modern yang diwujudkan secara baik dalam sistem pengajaran maupun pelajarannya

Keywords: modernization, system of education, pesantren.

\section{Pendahuluan}

Dalam struktur pendidikan nasional, pesantren merupakan mata rantai yang sangat penting. Hal ini tidak hanya karena sejarah kemunculannya yang relatif lama, tetapi juga karena pesantren telah secara signifikan ikut andil dalam upaya mencerdaskan kehidupan bangsa. Dalam sejarahnya, pesantren merupakan lembaga pendidikan yang berbasis masyarakat (society based-education). Dalam kenyataannya, pesantren telah mengakar dan tumbuh dari masyarakat, kemudian dikembangakan oleh masyarakat, sehingga kajian mengenai pesantren sebagai sentral pengembangan masyarakat sangat menarik beberapa peneliti akhir-akhir ini. Kendatipun pesantren atau populer pondok pesatren merupakan kenyataan sosial yang sudah mapan dalam masyarakat Indonesia, namun tidak memperoleh perhatian dan intervensi yang signifikan dari pemerintah untuk mengembangkan ataupun memberdayakannya. Hal ini menjadikan pesantren tumbuh dengan kemampuan sendiri yang pada akhirnya menumbuhkan pengaruh yang sangat besar, karena sangat tergantung pada kemampuan masyarakat itu sendiri. Arus globalisasi telah mempengaruhi segalanya dan merupakan tantangan tersendiri yang harus dihadapi oleh pesantren yaitu bagaimana merespon segala perubahan yang terjadi di dunia luarnya tanpa merubah dan meninggalkan identitas pesantren itu sendiri, sehingga pesantren tetap eksis di tengah-tengah masyarakat modern.

Perkembangan dunia telah melahirkan suatu kemajuan zaman yang modern. Perubahan-perubahan yang mendasar dalam struktur budaya masyarakat seringkali membentur pada aneka kemapanan. Akibatnya ada keharusan untuk mengadakan upaya kontekstualisasi bangunan-bangunan budaya masyarakat dengan dinamika modernisasi, tak terkecuali dengan sistem pendidikan pesantren. Karena itu sistem pendidikan pesantren harus melakukan upayaupaya konstruktif agar tetap relevan dan mampu bertahan.

Perbedaan yang paling nampak antara pesantren tradisional dengan pesantren modern adalah dalam mengembangkan potensi yang ada pada diri santri. Santri tidak hanya menonjol dalam hal etika (afektif) tetapi juga dapat 
mengembangkan usaha-usahanya melalui keterampilan yang ia miliki disamping kepekaan dalam melihat hal-hal yang baru. Dalam dunia pesantren, perubahan mendasar corak pesantren akibat globalisasi adalah perubahan dari tradisional ke modern yang merupakan representasi dari masyarakat modern. Kenyataan itu mendikotomikan pesantren menjadi pesantren tradisional yang dikenal memakai sistem salafi (mengkaji kitab kuning) dan pesantren modern yang tidak lagi mengajarkan kitab-kitab Islam klasik. Akses globalisasi tidak lantas menjadikan pesantren kehilangan orientasinya. Tetapi pesantren, terutama yang modern melakukan penyesuaian-penyesuaian dengan aturan-aturan modernitas, itulah yang disebut bahwa dunia modern mengakibatkan tiga hal sekaligus: globalisasi, detradisionalisasi, dan social reflexivity.

Menghadapi perubahan zaman yang begitu cepat, dunia pesantren mengalami pergeseran kearah perkermbangan yang lebih positif, baik secara struktural maupun kultural, yang menyangkut pola kepemimpinan, pola hubungan pimpinan dan santri, pola komunikasi, cara pengambilan keputusan dan sebagainya, yang lebih memperhatikan prinsip-prinsip manajemen ilmiah dengan landasan nilai-nilai Islam. Dinamika perkembangan pesantren semacam inilah yang menampilkan sosok pesantren yang dinamis, kreatif, produktif dan efektif serta inovatif dalam setiap langkah yang ditawarkan dan dikembangkannya, sehingga pesantren merupakan lembaga yang adaptif dan antisipatif terhadap perubahan dan kemajuan zaman dan teknologi tanpa meninggalkan nilai-nilai religius.

Tulisan ini berangkat dari dinamika zaman yang terus berjalan seiring dengan proses modernisasi, yang menuntut pesantren untuk mau menerima perubahan dan perkembangan. Melihat relita di atas, sebagai sebuah lembaga yang bergerak dalam bidang pendidikan dan sosial keagamaan, pengembangan pesantren harus terus didorong. Hal ini karena sudah tidak diragukan lagi bahwa pesantren memiliki kontribusi nyata dalam pembangunan pendidikan. Apalagi dilihat secara historis, pesantren memiliki pengalaman yang luar biasa dalam membina dan mengembangkan masyarakat. Melihat kenyataan tersebut, penulis beranggapan bahwa modernisasi pesantren menjadi suatu kebutuhan manusia yang seharusnya dipenuhi karena dapat mengatasi kesenjangan pola kehidupan yang terjadi antara dunia pesantren dengan perkembangan dunia luar, yang dalam hal ini adalah pendidikan (Islam) Indonesia. Selain itu, modernisasi juga sesuai dengan prinsip yang selama ini dipegang teguh dalam pesantren, "al muhafadzah 'ala al qadim al shalih, wa al akhdzu bi al jadid al ashlah", yaitu tetap memegang tradisi yang positif, dan mengimbangi dengan 
mengambil hal-hal baru yang positif. Ini berarti, pesantren dituntut melakukan kontekstualisasi tanpa harus mengorbankan watak aslinya.

Dari sini, penulis tertarik untuk mengkaji lebih dalam tentang modernisasi pola sistem pesantren dan pendidikan Islam Indonesia. Ada beberapa alasan yang mendorong penulis untuk memilih judul tersebut, diantaranya adalah:

1. Melihat kenyataan bahwa pesantren sebagai salah satu model pendidikan yang khas (indigenous) Indonesia, sehingga sangat menarik untuk diperbincangkan masyarakat.

2. Melihat banyaknya penilaian terhadap pesantren yang menyatakan bahwa pesantren adalah suatu lembaga pendidikan Islam yang sifatnya indoktrinatif, kaku, tidak mengikuti perkembangan.

3. Melihat adanya suatu kenyataan bahwa pesantren memiliki kontribusi nyata dalam pembangunan pendidikan, yaitu membina dan mengembangkan masyarakat.

\section{Tujuan dari penelitian ini adalah}

Mengetahui model modernisasi pendidikan pesantren, pertama dalam bidang personalia, yang merupakan penilaian sosial terhadap masing-masing tugas yang diberikan, kedua adalah fasilitas fisik yang diberikan oleh pesantren kepada guru atau santri di pesantren, dan yang terakhir adalah pengaturan waktu yang dilakukan oleh pesantren untuk kegiatan belajar mengajar, kegiatan keagamaan, kegiatan sosial.

Plus minus modernisasi pendidikan pesantren, adanya banyak pendapat yang pro dengan modernisasi pendidikan pesantren dapat berdampak pada kelebihan-kelebihan yang nantinya akan memajukan pendidikan pesantren sedangkan yang kontra berpendapat bahwa modernisasi pendidikan pesantren berdampak pada kelemahan-kelemahan yang akan mengikis pendidikan pesantren yang murni.

Pola pesantren modern. Salah satu yang paling berpengaruh pada model model modernisasi pendidikan pesantren adalah pola baik dari struktur organisasi, fasilitas, dan metode pembelajaran yang dipakai.

\section{Metode Penelitian}

Jenis penelitian ini adalah penelitian kualitatif dengan menggunakan model studi kasus, penelitian ini tidak ditujukan untuk menguji hipotesa oleh karena itu tidak menerapkan metode penghitungan statistik kuantitatif (Sutrisno, 2004:17). Sebagai penelitian studi kasus, maka langkah-langkah 
yang akan ditempuh dalam penelitian ini adalah sebagai berikut: melakukan pengumpulan data pada kasus pertama, yaitu Pesantren Daarul Fikri Mulyoagung Dau Malang. Penelitian ini dilakukan sampai pada tingkat kejenuhan data dan selama itu pula dilakukan kategorisasi dalam tema-tema untuk menemukan konsepsi tematik mengenai modernisasi pola sistem pendidikan pesantren.

Lokasi penelitian terletak di Pondok Pesantren Daarul Fikri Mulyoagung Dau Malang. Dengan pertimbangan Pesantren Daarul Fikri merupakan suatu lembaga independen yang tidak berafiliasi kepada organisasi atau golongan manapun. Hal ini menjadikan Daarul Fikri sebagai lembaga pendidikan yang mengedepankan kemurnian dan idealisme pendidikan yang terbebas dari kepentingan politik maupun golongan tertentu.

Peneliti memilih informasi yang dipandang paling mengetahui masalah yang dikaji. Penentuan informan dilakukan secara snowball. Key informan dalam penelitian ini adalah para Kiai maupun santri yang ada di Pondok Pesantren Daarul Fikri Mulyoagung Dau Malang. Penambahan dan wawancara dengan informan dilakukan hingga data yang didapat mencapai kejenuhan teoritik atau dengan kata lain dan yang diperoleh sama antara informan-informan berikutnya (Moleong, 2007:23).

Purposive sampling adalah teknik penentuan sampel untuk tujuan tertentu saja. Sampel yang dipilih adalah orang yang ahli dalam bidang keagamaan saja. Snowball sampling adalah teknik penentuan sampel yang mula-mula jumlahnya kecil, kemudian sampel ini disuruh memilih teman-temannya untuk dijadikan sampel. Begitu seterusnya, sehingga jumlah sampel semakin banyak (Sugiyono, 2009:72).

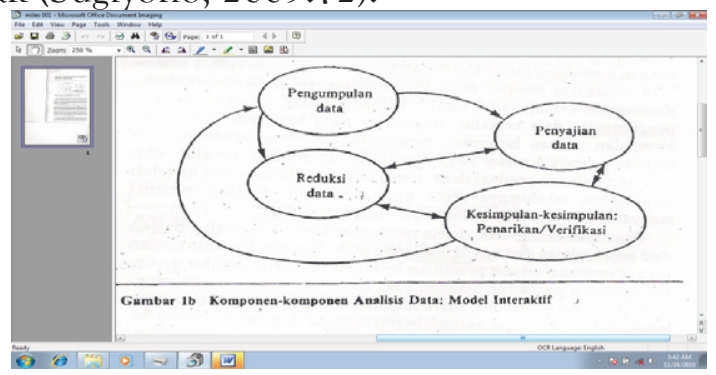

Gambar 1. Komponen-komponen Analis Data Model Interaktif Sumber: Milles dan Hubberman, 1992:20

\section{Modernisasi}

Modernisasi berasal dari kata modern yang berarti terbaru, mutakhir, atau sikap dan cara berpikir yang sesuai dengan tuntutan zaman. Selanjutnya 
modernisasi diartikan sebagai proses pergeseran sikap dan mentalitas sebagai warga masyarakat untuk bisa hidup sesuai dengan tuntutan masa kini. Modernisasi merupakan suatu proses yang ditandai dengan implementasi ilmu pengetahuan dan teknologi dalam segala segi kehidupan masyarakat (Kanto, 2006: 3). Dari pemaparan di atas, dapat dipahami bahwa modernisasi adalah suatu usaha secara sadar untuk menyesuaikan diri dengan konstelasi dunia dengan menggunakan kemajuan ilmu pengetahuaan, untuk kebahagiaan hidup sebagai perorangan, bangsa, atau umat manusia.

\section{Sejarah Modernisasi}

Sebagaimana telah dikemukakan di atas, modernisasi adalah suatu usaha secara sadar dari suatu bangsa atau negara untuk menyesuaikan diri dengan konstelasi dunia pada suatu kurun tertentu dengan mempergunakan kemajuan ilmu pengetahuan. Oleh karenanya, usaha dan proses modernisasi itu selalu ada dalam setiap zaman dan tidak hanya terjadi pada abad ke-20 ini. Hal ini secara historis dapat diteliti dan dikaji dalam perjalanan sejarah bangsa-bangsa di dunia.

Antara abad 2 sebelum masehi sampai abad ke-2 masehi, kerajaan Romawi menentukan konstelasi dunia. Banyak kerajaan di sekitar laut Mediteranian, kerajaan-kerajaan di Eropa Tengah dan Eropa Utara, secara sadar berusaha menyesuaikan diri dengan kerajaan Romawi, baik dalam kehidupan ekonomi, politik dan kebudayaan. Dalam melaksanakan program-program modernisasi demikian, tiap-tiap kerajaan tetap memelihara dan menjaga kekhasan masingmasing.

Modernisasi merupakan satu istilah yang menjadi mode setelah perang dunia ke-dua.akan tetapi menurut pengertiannya yang umum perkataan modern mencakup seluruh era sejak abad ke-18, ketika penumuan-penemuan seperti mesin uap dan mesin pemintal meletakkan landasan teknik yang pertama bagi industrialisasi di berbagai masyarakat. Berdasarkan pandangan seorang ahli sejarah yaitu Cyril Black, menyarankan dalam karangannya bahwa masyarakat modern ditandai oleh bertumbuhnya ilmu pengetahuan baru dan adanya manusia yang memiliki kemampuan yang semakin meningkat guna memahami rahasia-rahasia alam dan guna menerapkan pengetahuan ini dalam berbagai kegiatan manusia. Modernisasi masyarakat lahir dari struktur sosial yang ditandai oleh tidak adanya persamaan dan keadaan itu didasarkan atas ikatan-ikatan kekerabatan, hak-hak lainnya yang turun temurun, dan kekuasaan yang sudah mapan dengan kestabilan yang berbeda-beda (Soekanto, 1982: 17) 


\section{Dampak Modernisasi}

Sebagian masyarakat telah mengidentikkan begitu saja istilah modernisasi dengan istilah westernisasi. Padahal terdapat perbedaan esensial antara pengertian modernisasi dengan westernisasi. Westernisasi adalah mengadaptasi gaya hidup Barat, meniru-niru, dan mengambil alih cara hidup Barat. Jadi orang yang meniru-niru, mengambil alih tata cara hidup barat, mengadaptasi gaya hidup orang barat itulah yang lazim disebut westernisasi. Meniru gaya hidup berarti meniru secara berlebihan gaya pakaian orang barat dengan cara mengikuti mode yang berubah-ubah cepat, meniru cara bicara dan adat sopan santun pergaulan orang barat dan seringkali ditambah dengan sikap merendahkan bahasa nasional dan adat sopan santun pergaulan Indonesia, meniru polapola bergaul, pola-pola berpesta (merayakan ulang tahun), pola rekreasi, dan kebiasaan minum-minuman keras seperti orang barat, dan sebagainya. Orang Indonesia yang berusaha mengadaptasikan suatu gaya hidup kebarat-baratan seperti itulah yang disebut sebagai orang yang condong ke arah westernisasi. Orang Indonesia seperti itu belum tentu modern, dalam arti mentalitasnya modern. Ia bicara dengan gaya bahasa penuh ungkapan-ungkapan Belanda atau Inggris, memanggil si istri darling, disapa pappie atau daddy oleh anak-anaknya, minum bir bintang pagi dan sore, pergi berdansa tiap hari sabtu malam, suka nonton midnight show, merayakan ulang tahun semua anggota keluarganya satu demi satu dengan pesta-pesta mewah dan meriah, dan sebagainya.

\section{Pesantren}

Secara historis pesantren merupakan lembaga pendidikan Islam yang di kembangkan secara indigenous oleh masyarakat Indonesia. Karena sebenarnya pesantren merupakan produk budaya masyarakat Indonesia yang sadar sepenuhnya akan pentingnya arti sebuah pendidikan bagi orang pribumi yang tumbuh secara natural. Terlepas dari mana tradisi dan sistem tersebut diadopsi, tidak akan mempengaruhi pola yang unik dan telah mengakar serta hidup dan berkembang di tengah-tengah masyarakat. Pesantren merupakan institusi pendidikan Islam khas nusantara (Hajar, 2009: 34).

Pesantren berasal dari kata santri, dengan awalan pe dan akhiran an, berarti tempat tinggal santri, pesantren berasal dari kata santri yaitu seseorang yang belajar agama Islam, sehingga dengan demikian pesantren mempunyai arti tempat orang berkumpul untuk belajar agama Islam. Ada juga yang mengartikan pesantren adalah suatu lembaga pendidikan Islam Indonesia 
yang bersifat "tradisional" untuk mendalami ilmu tentang agama Islam dan mengamalkannya sebagai pedoman hidup keseharian. Definisi singkat istilah "pondok" adalah tempat sederhana yang merupakan tempat tinggal kiai bersama para santrinya (Hasbullah, 1999: 142).

\section{Elemen-Elemen Pesantren}

Pesantren pada umumnya terdiri atas lima elemen pokok, yaitu: kiai, santri, masjid, pondok dan pengajaran kitab-kitab Islam klasik. Kelima ciri tersebut merupakan ciri khusus yang dimiliki pesantren dan membedakan pondok pesantren dengan lembaga pendidikan lainnya.

\section{Kiai}

Kiai diartikan sebagi figur pemimpin pondok pesantren. Status ini didapat karena keturunan (ascribed status). Penyandangnya adalah seorang keturunan kiai (anak, saudara kandung, ipar, menantu) yang mempunyai keahlian dalam ilmu agama dan menjadi tokoh masyarakat serta fatwa-fatwanya selalu diperhatikan. Istilah kiai pada umumnya dipakai oleh masyarakat Jawa untuk menyebut orang lain bentuk jamak alim dalam bahasa Arab adalah ulama dalam tradisi masyarakat muslim. Kiai biasanya memiliki karisma dan pada umumnya memimpin sebuah pesantren, mengajarkan kitab-kitab klasik (kitab kuning) dan memiliki keterikatan dengan kelompok Islam tradisional (Dhofier, 1985: 55).

\section{Santri}

Santri adalah seorang anak atau seorang yang belajar atau menuntut ilmu pada sebuah pondok pesantren atau sebutan bagi para siswa yang belajar mendalami agama di pesantren. Istilah santri sebenarnya mempunyai dua konotasi atau pengertian. Pertama adalah mereka yang taat menjalankan perintah agama Islam. Dalam pengertian ini santri dibedakan secara kontras dengan mereka yang disebut kelompok abangan, yakni mereka yang lebih dipengaruhi oleh nilai-nilai budaya pra Islam, khususnya yang berasal dari mistisme Hindu dan Budha. Kedua santri adalah mereka yang tengah menuntut pendidikan di pesantren. Keduanya berbeda tetapi jelas mempunyai persamaan yaitu sama-sama taat dalam menjalankan syariat agama Islam.

\section{Masjid}

Masjid merupakan elemen yang tidak dapat dipisahkan dengan pesantren 
dan dianggap sebagai tempat yang paling tepat untuk mendidik para santri, terutama dalam praktek sholat lima waktu, khotbah, sholat jum'at dan pengajian kitab-kitab Islam klasik. Kata mesjid itu berasal dari bahasa Arab: masjid. Dalam kalangan orang-orang yang beragama dipakai kata Arab: masjid, tetapi ucapannya dalam bahasa daerah di Indonesia mengalami sedikit perubahan, dalam bahasa Jawa diucapkan mesigit, dalam bahasa Sunda masigit, dalam bahasa Madura maseghit, di Jakarta masjid (antara a dan e) diucapkan oleh orang-orang yang taat yang lainnya mesigit (Pijper, 1984: 15).

\section{Pondok}

Kata pondok berarti tempat yang dipakai untuk makan dan istirahat. Istilah pondok dalam konteks dunia pesantren berasal dari pengertian asrama-asrama bagi para santri. Perkataan pesantren berasal dari kata santri, yang dengan awalan "pe" di depan dan akhiran "an" berarti tempat tinggal para santri (Dhofier 1985:18). Maka pondok pesantren adalah asrama tempat tinggal para santri. "Pondok pesantren mirip dengan akademi militer atau biara (monestory, convent) dalam arti bahwa mereka yang berada di sana mengalami suatu kondisi totalitas" (Wahid, 2001:171). Sekarang di Indonesia ada ribuan lembaga pendidikan Islam terletak diseluruh nusantara dan dikenal sebagai dayah dan rangkang di Aceh, surau di Sumatra Barat, dan pondok pesantren di Jawa (Azra, 2001: 70).

\section{Pengajaran Kitab-Kitab Islam Klasik atau Kitab Kuning}

Berbicara tentang pondok pesantren, tidak dapat terlepas kaitannya dengan kitab-kitab Islam klasik atau yang sering disebut dengan kitab kuning. Pada dasarnya pesantren itu adalah lembaga kajian dan pengembangan kitab kuning. Kitab-kitab Islam klasik dikarang para ulama terdahulu dan termasuk pelajaran mengenai macam-macam ilmu pengetahuan agam Islam dan bahasa Arab. Dalam kalangan pesantren, kitab-kitab Islam klasik sering disebut kitab kuning oleh karena warna kertas edisi-edisi kitab kebanyakan berwarna kuning.

Kitab kuning dalam pendidikan agama Islam, merujuk kepada kitab-kitab tradisional yang berisi pelajaran-pelajaran agama islam (diraasah al islamiyyah) yang diajarkan pada Pondok Pesantren, mulai dari figh, aqidah, akhlaq/tasawuf, tata bahasa Arab ('ilmu nahwu dan 'ilmu sharf), hadits, tafsir, 'ulumul qur'aan, hingga pada ilmu sosial dan kemasyarakatan (mu`amalah). Dikenal juga dengan 
kitab gundul karena memang tidak memiliki harakat (fathah, kasrah, dhammah, sukun), tidak seperti kitab al Quran pada umumnya. Oleh sebab itu, untuk bisa membaca kitab kuning berikut arti harfiah kalimat per kalimat agar bisa dipahami secara menyeluruh, dibutuhkan waktu belajar yang relatif lama.

\section{Hasil dan Pembahasan}

\section{Model Modernisasi Pendidikan Pesantren}

Modernisasi atau inovasi pendidikan pesantren dapat diartikan sebagai upaya untuk memecahkan masalah pendidikan pesantren. Atau dengan kata lain, inovasi pendidikan pesantren adalah suatu ide, barang, metode yang dirasakan atau diamati sebagai hal yang baru bagi seseorang atau sekelompok orang , baik berupa hasil penemuan (invention) maupun discovery yang digunakan untuk mencapai tujuan atau memecahkan masalah pendidikan pesantren. Inovasi (modernisasi) pendidikan adalah sebagai berikut:

a. Bidang personalia

Pendidikan yang merupakan bagian dari sistem sosial, tentu menentukan personal sebagai komponen sistem. Inovasi yang sesuai dengan komponen personel misalnya adalah peningkatan mutu guru, sistem kenaikan pangkat, dan sebagainya. Dalam hal ini, pesantren telah di bantu dengan adanya program beasiswa S1 untuk guru diniyah oleh Departemen Agama.

b. Fasilitas fisik

Inovasi pendidikan yang sesuai dengan komponen ini misalnya perubahan tempat duduk, perubahan pengaturan dinding ruangan perlengkapan laboratorium bahasa, laboratorium komputer dan sebagainya.

c. Pengaturan waktu

Suatu sistem pendidikan tentu memiliki perencanan penggunaan waktu. Inovasi yang relevan dengan komponen ini misalnya pengaturan waktu belajar, perubahan jadwal pelajaran yang dapat memberi kesempatan siswa/mahasiswa untuk memilih waktu sesuai dengan keperluannya, dan lain sebagainya.

Menurut Kiai Sumhudi, yang paling penting untuk direvisi adalah kurikulum pesantren yang biasanya mengalami penyempitan orientasi kurikulum. Maksudnya, dalam pesantren terlihat materinya hanya khusus yang disajikan dalam bahasa Arab. Mata pelajarannya meliputi fiqh, aqa'id, nahwu sharf, dan lain-lain. Sedangkan tasawuf dan semangat keagamaan yang merupakan inti dari kurikulum keagamaan cenderung terabaikan. Tasawuf hanya dipelajari sambil lalu saja, tidak secara sungguh-sungguh. Padahal justru inilah yang lebih berfungsi dalam masyarakat zaman modern. Disisi 
lain, pengetahuan umum nampaknya masih dilaksanakan secara setengahsetengah, sehingga kemampuan santri biasanya sangat terbatas dan kurang mendapat pengakuan dari masyarakat umum. Maka dari itu, Kiai Sumhudi menawarkan kurikulum Pesantren Modern Daarul fikri sebagai model modernisasi pendidikan pesantren.

Jadi menurut saya, pendidikan merupakan salah satu dimensi terpenting dalam kehidupan manusia, sebab pada dasarnya pendidikan adalah ikhtiar transformasi yang dilakukan secara sadar, sistematis dan termanajemen guna membentuk karakter manusia yang bersendikan tradisi dan akhlak al karimah demi kehidupan yang baik dan sejahtera. Di pesantren sendiri, tradisi menjadi landasan pijak pendidikan utama sebagai bentuk komitmen kultural kepada bangsa, selain juga akhlak al karimah sebagai penuntun agar setiap upaya transformasi dalam pendidikan berjalan sesuai dengan rel yang telah digariskan oleh al Quran dan hadits. Keduanya, baik tradisi dan akhlak al karimah bagaimanapun akan sangat mempengaruhi pola hidup manusia secara individu maupun sosial.

Pola dasar pendidikan pesantren terletak pada relevansinya dengan segala aspek kehidupan. Dalam hal ini, pola dasar tersebut merupakan cerminan untuk mencetak santrinya menjadi insan yang shalih dan akram. Shalih, berarti manusia yang secara potensial mampu berperan aktif, berguna, dan terampil dalam kaitannya dengan kehidupan sesama makhluk. Sementara akram merupakan pencapaian kelebihan manusia sebagai makhluk terhadap khaliq-Nya, untuk mencapai kebahagiaan di akhirat.

Konsepsi 'shalih' dan 'akram' sebagaimana dikonsepsikan oleh Kiai Sumhudi merupakan penegasan sebagai upaya sinergi antara tradisi dan modernitas. Sinergi tersebut adalah proyek pendidikan pesantren masa depan. Artinya, pendidikan pesantren masa depan adalah pendidikan yang berorientasi pada modernitas dan tetap berpijak pada tradisi.

Proses pendidikan di pesantren berjalan langsung 24 jam. Interaksi antara kiai, ustadz, dan santri berjalan sedemikian intens. Interaksi dalam pendidikan tersebut dibangun atas fondasi tradisi dan akhlak al karimah. Saling hormat-menghormati, kesederhanaan, keikhlasan, dan ketawadluan. Untuk mewadahi minat dan bakat para santri, pesantren juga memfasilitasi mereka dengan beragam ekstrakurikuler, beberapa di antaranya antara lain seni baca al Quran (qira'ah), seni kaligrafi, seni bela diri, seni sastra, dan lain sejenisnya (Wawancara Kiai Sumhudi, 10 Mei 2010)

Dan kalau dilihat prospeknya kedepan pendidikan di pesantren memiliki 
peluang besar untuk mengembangkan pendidikannya dengan membuka berbagai program pendidikan yang diminati banyak orang, salah satunya adalah pendidikan ekonomi Islam. Jadi pondok pesantren tidak hanya fokus di bidang ilmu keagamaan semata. Pada dasarnya sistem pendidikan sekolah umum dan pesantren tidak perlu dibeda-bedakan, karena keduanya memiliki tujuan yang sama yakni bagaimana menciptakan kader pemimpin masa depan bangsa yang memiliki kepribadian yang luhur. Namun secara sistem, pondok pesantren lebih kompleks dalam mengajarkan konten-konten yang berhubungan dengan ilmu agama, dalam hal ini islam. Baik dari segi ilmu sosial, budaya, ekonomi dan pendidikan, semuanya dibahas dengan komprehensif didalam pesantren. Inilah salah satu kelebihan pesantren dari pada pendidikan umum yang ada. Adalah suatu keunikan tersendiri, jika pesantren hingga saat ini tetap survive di tengah gejolak modernisasi dan globalisasi sekalipun. Lembaga pendidikan yang kerap distigmatisasi 'tradisional' ini, telah menunjukkan eksistensinya, bahwa ia tetap istiqamah dengan tradisionalismenya, tanpa kehilangan iklusivitas dan kontekstualitas.

Betapa tidak, di tengah kondisi bangsa dengan realitas pendidikan dan pola hidup masyarakatnya yang carut marut, kita akan jengah saat melihat realitas pendidikan yang mengemuka penuh dengan perilaku destruktif-amoralitas yang pada akhirnya berimbas pada pola hidup koruptif dan manipulatif para elit pejabat yang mengakar sampai masyarakat alit pada umumnya. Di sinilah letaknya, betapa saat ini kita butuh penyegaran dan perbaikan agar gejala distorsif tersebut tidak mewabah dan menjalar semakin parah.

\section{Plus Minus Modernisasi Pendidikan Pesantren}

Pesantren pada awal mulanya merupakan lembaga pendidikan yang concern pada pendidikan keagamaan (tafaqquh fi al din) sebagai bentuk keterpangigilan hati betapa pendidikan itu penting di atas kepentingan apapun. Pesantren sadar betul pentingnya mengedepankan pendidikan selain merupakan satu bentuk kebertahanan dan perlawanan atas penjajahan kolonial saat itu, juga untuk menyongsong kemajuan dalam menatap masa depan bangsa dan agama.

Dalam menanggapi gagasan ini, tampak kalangan pesantren terbelah menjadi dua, yaitu pro dan kontra. Adanya kontroversi ini mungkin lebih disebabkan pada perbedaan pendapat mereka tentang bagaimana sikap pesantren dalam menghadapi era globalisasi. Mereka yang pro mengatakan bahwa modernisasi pesantren akan memberi angin segar bagi pesantren. Mereka menganggap bahwa banyak sisi positif yang akan diperoleh dengan modernisasi pendidikan di pesantren. Di antara sisi positif tersebut adalah 
sebagai berikut:

1. Sebagai bentuk adaptasi pesantren terhadap perkembangan era globalisasi. Hal ini mutlak harus dilakukan agar pesantren tetap eksis.

2. Sebagai upaya untuk memperbaiki kelemahan dalam sistem pendidikan pesantren.

3. Sedangkan bagi kalangan pesantren yang tidak setuju dengan gagasan modernisasi berpendapat bahwa gagasan tersebut banyak sisi negatifnya, diantaranya adalah:

4. Modernitas akan merubah cara pandang lama terhadap dunia dan manusia.

5. Modernisasi sistem pendidikan tradisional dikhawatirkan akan ikut merubah kultur-kultur positif yang telah lama terbentuk di pesantren.

Terlepas dari polemik tersebut, perbedaan pendapat yang terjadi telah mendatangkan sisi positif tersendiri bagi pesantren. Hal itu telah dibuktikan hadits Nabi Muhammad Saw "ikhtilafu ummati rahmatun" yang artinya "perbedaan pendapat dalam umatku adalah rahmat". Diantara manfaat dari perbedaan pendapat dalam masalah ini adalah:

1. Melahirkan banyak pesantren yang bervariasi. Banyak pesantren yang memiliki ciri khas masing-masing. Ini memberikan banyak pilihan kepada calon santri dalam menentukan pesantren yang sesuai dengan bakat, minat serta cita-citanya.

2. Lahirnya santri yang beraneka ragam. Hal ini mengubur paradigma bahwa santri hanya mampu di bidang agama saja. Saat ini banyak sekali santri yang ahli di bidang pengetahuan umum.

Gagasan modernisasi dianggap perlu dilakukan oleh beberapa kalangan, salah satunya adalah Kiai Sumhudi. Ia berpendapat bahwa modernisasi ini sebaiknya dilakukan dengan model sistem pendidikan Pesantren Modern Daarul Fikri. Namun gagasan ini telah memecah kalangan pesantren menjadi dua kubu, pro dan kontra. Namun kontroversi ini telah menimbulkan variasi tersendiri dikalangan pesantren. Ini merupakan salah satu sisi positif dari perbedaan pendapat yang terjadi di kalangan pesantren.

\section{Pola Pesantren Modern}

Pondok pesantren selain memiliki komponen-komponen fisik seperti tempat untuk pendidikan ketrampilan seperti kerajinan, perbengkelan, toko, koperasi, sawah, ladang dan sebagainya. Sehingga sebagai sarana edukatif lainnya 
sebagai penunjang memiliki nilai lebih. Dalam pola yang terakhir ini pondok pesantren telah berkembang dengan pesatnya sesuai dengan perkembangan zaman dan yang lazim disebut dengan pondok pesantren moderen atau pondok pesantren pembangunan. Disamping masjid, rumah kiai/ustadz, pondok, madrasah dan atau sekolah umum, terdapat pula bangunan-bangunan fisik lainnya sebagai penunjang seperti; perpustakaan, dapur umum, rumah makan umum, kantor administrasi, toko/unit usaha, koperasi sebagainya.

Sedangkan menurut klasifikasi Ziemek dapat dikategorikan pola pesantren modern, antara lain:

Merupakan kelompok pesantren yang ditambah dengan lembaga pendidikan, yaitu terdapat komponen kiai, masjid, santri, pondok, madrasah (primer). Aktifitas di pondok jenis ini dimaksudkan agar siswa/santri dapat memahami pengetahuan agama dan pengetahuan umum yang berlaku secara internasional. Dan dalam menempuh pendidikan di lembaga ini diakui oleh pemerintahan.

Merupakan kelompok pesantren yang memiliki fasilitas lengkap dengan pemahaman elemen madrasah (primer, sekunder, dan tersier), yaitu lembaga pendidikan yang formal dari tingkat dasar hingga perguruan tinggi, dengan fasilitas belajar mengajar yang lengkap, seperti laboratorium dan perpustakaan untuk menunjang proses belajar pesantren.

Merupakan kelompok pesantren besar dan berfasilitas lengkap, terdiri dari pesantren induk dan pesantren cabang. Di sini terdapat penambahan elemen madrasah dari yang primer hingga tersier dan fasilitas penunjang ruang keterampilan. Pesantren induk hanya diperuntukan bagi santri yang telah tamat dalam penguasaan kitab-kitab Islam, dan hanya tinggal pematangan watak dan penggemblengan rohani secara rutin serta penguasaan bahasa pengantar dasar pendidikan, yaitu Bahasa Arab. Sedangkan pesantren cabang merupakan tempat penggemblengan dasar-dasar penguasaan dan pemahaman kitab-kitab Islam serta beberapa pengenalan keahlihan dan keterampilan.

Pesantren mengalami perubahan yang sangat signifikan karena berlangsungnya modernisasi pesantren di Jawa sejak masa orde baru. Dalam perubahan-perubahan itu, pesantren kini memiliki empat jenis pendidikan yaitu pendidikan yang berkonsentrasi pada tafaqquh fi al din, pendidikan berbasis madrasah, pendidikan berbasis sekolah umum dan pendidikan berbasis ketrampilan. Modernisasi pesantren telah banyak mengubah sistem dan kelembagaan pendidikan pesantren. Perubahan yang sangat mendasar misalnya terjadi pada aspek-aspek tertentu dalam kelembagaan. 
Modernisasi yang dilakukan Pesantren Daarul Fikri sangat berbeda dengan pesantren-pesantren yang lain di Indonesia. Pesantren Daarul Fikri telah memberlakukan kurikulum yang sangat ketat. Santri harus mengikuti seluruh peraturan dalam pendidikan secara reguler dan patuh. Kurikulum Daarul Fikri mencoba memadukan antara tradisi belajar klasik dengan gaya modern yang diwujudkan secara baik dalam sistem pengajaran maupun pelajarannya (Wawancara pengurus pondok, 17 Juli 2011).

Sebenarnya gagasan modernisasi pesantren bertitik tolak dari modernisasi pendidikan Islam yang mempunyai akar-akar dalam gagasan tentang modernisasi pemikiran dan institusi Islam secara keseluruhan yaitu modernisasi pemikiran dan kelembagaan Islam yang merupakan prasyarat bagi kebangkitan kaum muslimin dimasa modern. Karena itu pemikiran kelembagaan Islam (termasuk pendidikan) harus dimodernisasi sesuai dengan kerangka modernitas.

Modernisasi yang dilakukan beberapa pesantren tersebut tidak seperti yang dilakukan dari sekolah umum plus yang dikembangkan di kalangan modernis. Mungkin modernisasi yang dilakukan pesantren mengacu pada pembentukan kreativitas dan daya kritis santri seperti yang semula menggunakan sistem halaqoh dan sorogan yang menekankan aspek kongnitif serta memandang santri untuk mandiri, seperti di Pesantren Daarul Fikri. Tetapi adanya opini yang cukup kuat, modernisasi pesantren dilakukan karena adanya ekspansi dari sekolah umum plus, sehingga pesantren memasukkan ilmu-ilmu umum dalam kurikulum pesantren.

Jadi menurut saya, pola modernisasi Pesantren Daarul Fikri untuk membangun bentuk pendidikan yang solid, Pesantren Daarul Fikri memiliki tiga pilar dasar dalam menjalankan proses belajar-mengajarnya yang berjalan selama 24 jam itu. Tiga pilar itu adalah iman sempurna, ilmu luas dan amal sejati.

Pilar yang pertama adalah iman sempurna adalah manifestasi dari hubungan yang erat antara kehidupan dan kekuasan yang dimiliki Allah, sehingga segala sesuatu yang terjadi diyakini adalah kehendak Allah, baik itu berupa pencapaian positif maupun negatif. Dengan demikian, orientasi pendidikan lebih diutamakan adalah penjelmaan dari ibadah. Ini dilandasi oleh hadits nabi yang menyatakan orang yang menuntut ilmu adalah syahid jika kemudian meninggal dunia.

Pilar yang kedua adalah berilmu luas. Semua ilmu tidak hanya terbatas pada pelajaran agama diberikan kepada pondok. Ilmu-ilmu sains, berupa fisika, biologi, kimia, geografi dipelajari dengan internalisasi nilai-nilai Islam yang 
sebetulnya telah menjabarkan berbagai hal mengenai ilmu-ilmu tersebut. Santri pun diberikan keleluasan untuk mendalami berbagai ilmu dengan fasilitas berupa laboratorium yang telah tersedia lengkap dengan peralatannya. Selain itu, bahasa sumber ilmu pengetahuan pun dipelajari dengan lebih mendalam dan praktis (Bahasa Arab dan Inggris yang kemudian dijadikan sebagai alat komunikasi mutlak).

Pilar ketiga adalah beramal sejati. Tafsiran dari kata beramal sejati ini adalah segala hal yang dilakukan baik santri, muallim (baca: pengurus), dan ustadz dilandaskan pada amal. Sehingga segala sesuatunya dijalani dan diterima dengan ikhlas. Sehingga yang mentransformsikan ilmu dan yang ditransformasikan sama-sama samina wa atana (menerima dan memberi secara ikhlas).

\section{Simpulan}

Kelembagaan Islam termasuk pendidikan (pesantren) haruslah dimodernisasi yaitu diperbaharui sesuai dengan kerangka modernitas. Dengan kata lain, mempertahankan pemikiran kelembagaan Islam tradisional akan memperpanjang nestapa ketertinggalan umat Islam dalam kemajuan dunia modern. Arus globalisasi telah mempengaruhi segalanya dan merupakan tantangan tersendiri yang harus dihadapi oleh pesantren yaitu bagaimana merespon segala perubahan yang terjadi di dunia luarnya tanpa merubah dan meninggalkan identitas pesantren itu sendiri. Sehingga pesantren tetap eksis di tengah-tengah masyarakat modern.

Gagasan modernisasi dianggap perlu dilakukan karena modernisasi ini sebaiknya dilakukan dengan model sistem pendidikan Pesantren Modern Daarul Fikri. Namun gagasan ini telah memecah kalangan pesantren menjadi dua kubu, pro dan kontra. Namun kontroversi ini telah menimbulkan variasi tersendiri dikalangan pesantren. Ini merupakan salah satu sisi positif dari perbedaan pendapat yang terjadi di kalangan pesantren. Modernisasi pendidikan pesantren adalah perombakan pola pikir dan tata kerja lama yang tidak rasional dan menggantinya dengan pola pikir dan tata kerja baru yang rasional terkait dengan pendidikan pesantren.

Pesantren modern tidak hanya mengajarkan agama saja, tetapi juga mengajarkan ilmu-ilmu umum, ketrampilan dan sebagainya sebagaimana yang kita ketahui pada Pondok Pesantren Daarul Fikri, yang sudah menerapkan sistem dan metode yang menggabungkan antara sistem pengajaran non klasikal (tradisional) dan sistem klasikal (sekolah). Tujuan pondok pesantren 
adalah suatu lembaga pendidikan dan keagamaan yang berusaha melestarikan, mengajarkan dan menyebarkan ajaran Islam serta melatih para santri untuk siap dan mampu mandiri. Atau dapat juga diambil pengertian dasarnya sebagai suatu tempat dimana para santri belajar pada seseorang kiai untuk memperdalam atau memperoleh ilmu, utamanya ilmu-ilmu agama yang diharapkan nantinya menjadi bekal bagi santri dalam menghadapi kehidupan di dunia maupun akhirat.

Dari pembahasan di atas dapat disimpulkan bahwa pesantren khalaf adalah lembaga pesantren yang memasukkan pelajaran umum dalam kurikulum madrasah yang dikembangkan, atau pesantren yang menyelenggarakan tipe sekolah-sekolah umum seperti SMP, SMU dan bahkan perguruan tinggi dalam lingkungannya.

Sedikitnya terdapat dua cara yang dilakukan pesantren dalam merespon perubahan ini. Pertama, merevisi kurikulumnya dan memasukkan mata pelajaran dan ketrampilan umum. Kedua, membuka kelembagaan dan fasilitas pendidikannya bagi kepentingan pendidikan umum. Untuk itu pesantren yang menerima modernisasi harus benar-benar selektif dalam menerima dan mengadopsi pola-pola dari luar.

Karena bisa jadi pesantren yang tidak selektif dalam mengikuti perkembangan modernisasi ini akan kehilangan ruh dan identitasnya sebagai lembaga pendidikan pesantren. Pemikiran dan kelembagaan Islam termasuk pendidikan (pesantren) haruslah dimodernisasi yaitu diperbaharui sesuai dengan kerangka modernitas. Dengan kata lain, mempertahankan pemikiran kelembagaan Islam tradisional akan memperpanjang nestapa ketertinggalan umat Islam dalam kemajuan dunia modern.

\section{Saran}

Perbedaan pendapat adalah hal yang biasa dalam menyikapi suatu gagasan. Maka dari itu tidak perlu dibesar-besarkan. Kalangan pesantren harus bisa bersikap dewasa dan dalam hal ini harus berpikir positif. Memodernisasi pendidikan pesantren tidak harus menghilangkan ciri khas kepesantrenannya yaitu kemurnian Islamnya.

\section{Daftar Pustaka}

Azra, Azyumardi. 2000. Pendidikan Islam,Tradisi dan Modernisasi Menuju Melinium Baru. Jakarta: Logos Wacana Ilmu.

Dhofier, Zamakhsyari. 1985. Tradisi Pesantren: Studi Tentang Pandangan 
Hidup Kiai. Jakarta: LP3ES.

Dhofier, Zamakhsyari. 1981. Sikap Hidup dalam Lingkungan Pesantren serta kaitannya dengan Nilai-nilai Budaya dalam Pembangunan Bangsa, Analisis Kebudayaan. Jakarta: LP3ES.

Hajar, Ibnu. 2009. Kiai di Tengah Pusaran Politik. Yogyakarta: IRCiSoD.

Hasbullah, 1999. Sejarah Pendidikan Islam di Indonesia: Lintasan Sejarah Pertumbuhan dan Perkembangan. Jakarta: PT Raja Grafindo Persada.

Hubberman, Milles.1992. Analisis Data Kualitatif: Buku Sumber Tentang Metode-Metode Baru. Jakarta: UI Press.

Kanto, Sanggar. 2006. Modernisasi dan Perubahan Sosial (Suatu Kajian dari Perspektif Teori dan Empirik). Malang: Fakultas Pertanian Universitas Brawijaya.

Moleong, Lexy J. 2007. Metodologi Penelitian Kualitatif: Bandung: Rosdakarya.

Pijper. 1984. Sejarah Islam di Indonesia. Jakarta: Universitas Indonesia (UI- Press).

Soekanto, Soerjono. Sosiologi, Suatu Pengantar, Edisi Baru Kesatu 1982. Jakarta: CV Rajawali.

Sugiyono, 2009. Metode Penelitian Kuantitatif Kualitatif. Bandung: Alfabeta.

Sutrisno, Hadi. 2004. Metodologi Research. Yogyakarta: Penerbit Andi.

Wahid, Abdurrahman. 2001. Menggerakkan Tradisi: Esai-Esai Pesantren. Yogyakarta: LKIS. 